\title{
Could Motor Development Be an Emergent Property of Vestibular Stimulation and Primary Reflex Inhibition? A Tentative Approach to Sensorimotor Therapy
}

\author{
Mats Niklasson \\ Department of Psychology, Karlstad University, Karlstad \\ Sweden
}

\section{Introduction}

It was through the concern to meet the needs of the intelligent but under achieving child that the 'modern' field of learning disabilities was born. That said, we must keep in mind that it also started with a deep concern for the mentally retarded and a hopeful vision and conviction that fulfillment of the human potential was possible. The aim of this chapter is to provide tentative arguments in favor of a complementary view of the learning disabled child's ability to mature and to learn. My approach is based upon the necessity and importance of the body as a fundamental tool in the learning process but I will start with a historical overview of learning disabilities in general. To enable the reader to get a better understanding of the coherence between the different concepts which I wish to unite, I will give brief historical backgrounds as I proceed. These historical backgrounds also serve the purpose of showing that whilst my conclusion might be new, its different parts have long been in front of our eyes awaiting discovery. Through knowledge of history we are also better prepared for the future. However, the history of science has shown so many times before that a synthesis between different disciplines is needed in order for further progress to occur.

\section{Historical overview}

\subsection{The wild boy of Aveyron}

The written history of learning disabilities may be said to have started (Strauss \& Lehtinen, 1947) in 1799 with the physician and educator Jean-Marc Gastard Itard (1775-1838). Living in France, Itard discovered the 'wild boy' Victor. Although diagnosed as an 'idiot' and incurable by the father of scientific psychiatry, Philippe Pinel (Flugel, 1933), Itard was convinced that the boy could be educated into 'an acceptable human being'. As a man of his time, Itard was shaped by the spirit of the French Revolution and the philosophy of an inherent limitless possibility of human development. Being a physician for the deaf he used the same sensory training for Victor as he used for speech training with his patients. Although Victor's social behavior improved, his intelligence and ability to comprehend remained below expectation. Itard felt his experiment was a failure but published the 
training and the teaching in a book, 'The wild boy of Aveyron' $(1801 ; 1806 ; 1932)$. All of the teaching and training carried out has become of great significance (Flugel, 1933) because it was the first systematic attempt to train someone 'feeble-minded'. His work was successfully continued by one of his medical students, Edouard Séguin (1812-1880). Influenced by the utopian socialist Count de Saint-Simon, Séguin believed that educating the mentally disabled was a step toward a better society (www.newworld encyclopedia.org). By 1828, a special institute for the education of the mentally disabled had already been established in Paris and in 1842 Séguin became its director. Like his teacher, Séguin rejected the notion (Anastasi \& Urbina, 2007) that mental retardation was incurable and practiced sense training and muscle training for the benefit of his patients. At the time (Strauss \& Lehtinen, 1947), his work was in line with medical science which proposed specific training of those senses which were impaired as a way to improve the function of the nervous system. In 1846 Séguin wrote "you can't teach a child to read and write until its sensory system is mature" (Holle, 1990) and still today (Anastasi \& Urbina, 2007), the methods used for training mentally disabled children in sensory discrimination and motor control have their origin in Séguin's work and in no small way Maria Montessori's work was also influenced by him.

\subsection{Simon and Binet}

By the mid 19th century (Strauss \& Lehtinen, 1947), the first institutes created according to the French model were established in USA and in Great Britain. However, by the end of the century, due to effective laws regulating the compulsory education of children, educators in the US were troubled with a new problem. For a couple of months each year (Ravitch, 2000), $95 \%$ of the children aged five to thirteen attended school. Among these children were those who showed various degrees of retarded intellectual development with a decreased ability to understand and to learn but who still were too able to be institutionalized. As a consequence of the need to separate the mentally deficient student from the normal, Binet and Simon developed an intelligence test. The first scale presented in 1905 (Anastasi \& Urbina, 2007), included sensory and perceptual skills but as Binet held reasoning, judgment and comprehension as essential for intelligence, the test stressed the verbal content. However useful, the test, or more correctly the concepts used failed to fully distinguish mentally deficient children from the mentally retarded. Binet and Simon wrote in 1914 as cited in Strauss and Lehtinen (1947);

"....the division, which we have ourselves suggested, of all the abnormal into three groups: (1) the mentally defective; (2) the ill-balanced; (3) a mixed type which includes those who are both mentally defective and ill- balanced. The simply defective do not present any well defined anomaly of character, but they do not profit, or profit very little from ordinary school teaching. The ill-balanced, who might also be called the "undisciplined," are abnormal chiefly in character. They are distinguished by their unruliness, their talkativeness, their lack of attention, and sometimes their wickedness"(p. 12).

It is interesting to compare these lines to current descriptions of children with various difficulties and diagnoses. Simon and Binet seem to have roughly defined both the slow learner and the restless child but in the years to come the concepts would be further differentiated and refined. Doll, Phelps and Melcher (1932) postulated that mental retardation seen in children with cerebral palsy was not a direct effect of brain injury but 
rather due to the lack of ability to move and to explore. An important step was taken (Strauss \& Lehtinen, 1947) when science was able to distinguish between syndromes of endogeneity and exogeneity in mental deficiency. Larsen (1931) summarized (in Strauss and Lehtinen, 1947) the exogenous features as "organic with acquired neurological symptoms (birth-injury, encephalitis, meningitis)". Kahn and Cohen (1934) described what they labeled 'Organic drivenness' as a consequence for some children surviving encephalitis epidemica. The primary symptom was hyperkinesis but the child also showed an inability to keep quiet, clumsiness and abruptness in the performance of movements. Silver (1951) includes in his review of the 'organic child' the hypokinetic child. This child often displays lags in language development and in motor abilities. He is extremely rigid, clings to a parent and avoids or expresses anxiety in 'anti-gravity' play. Silver suggests that both the hyperkinetic and the hypokinetic child should be tested for primitive - and postural reflexes and concludes; "There exists a large number of children with behavior disorder in whom organic signs as described in this paper are found but in whom no etiological factor can definitely be established. It is often difficult even to determine whether the organic state is developmental or acquired. Many we suspect are developmental, but in others the role of trauma or anoxia at birth is by no means ruled out" (p.42). Once again it is tempting to compare the description with present day reality. It is scary to think about all those children and youngsters who might have been regarded as mentally retarded when their problem might have been of a sensorimotor character. I will return to this below.

\subsection{Towards a science of learning disabilities}

The concept 'organic' is used to describe structural or 'real' diseases/disorders, "of known structural, chemical, or metabolic origin", in the domain of the neurologist as opposed to functional disorders, for example psychosomatic diseases/disorders, mainly treated by psychiatrists (Black's Medical Dictionary, 1990; The Merk Manual, 1989; Bloom \& Lazerson, 1988). Body image (Schilder, 1964), for example, is based on physiological data and on the structural organization of the organism, but the final synthesis comes from the personality. However, as Bloom and Lazerson (1988) claim, the organic nature of a brain problem might be diagnosed as functional, whilst not being totally functional, due to an inability to measure the appropriate index. I will return to this problem below.

Mabel Todd, a contemporary of Larsen, Kahn and Cohen, defined proprioceptive sensations as organic (Todd, 1937) and grouped them into three types according to their origin (1). Kinesthesia, the feeling of movement. (2). Vestibular sensations, the feeling of position in space. (3). Visceral sensations, impressions from internal organs. In 1870, Ewald Hering (Finger, 1994) already used the term some what differently, in connection with memory, suggesting that 'organic memory' was more than just a part of the higher nervous system although his extension of these ideas was, and still is, very questionable. However controversial, I will return to 'organic memory' later.

In the mid 1930s, Orton made the suggestion (Ahonen, Kooistra, Viholainen, \& Cantell, 2004) that 'dyspraxia' or abnormal clumsiness was a developmental disorder to be found among dyslexic children. Not only were these children late in learning to walk and run, they were also late in visuomotor and manual tasks. In his book 'Reading, writing and speech problems in children' (1937), Orton developed the idea that clumsy children could have 
difficulties both in learning more complex body movements and in learning movements which are necessary for speech and writing. The following citations from Orton will serve as a background and as a bridge to my argumentation for sensorimotor therapy which follows below;

"Such children are often somewhat delayed in learning even the simpler movements such as walking and running, and have great difficulty in learning to use their hands and to copy motions showed to them. They are slow in learning to dress themselves and are clumsy in their attempts to button their clothes, tie their shoes, handle a spoon, and in other simple tasks"(p.121) .

"In the case of children who have great trouble in learning complex patterns of movement the developmental apraxias - simpler movements are often readily acquired although they may be lacking in grace or smoothness. Here the controlling sensory element is that of kinaesthesis or the registration of movement patterns" (p.148).

"Our attention has been directed to attempting to determine very simple patterns of movement over which the child has a reasonable mastery, and gradually combining these simpler patterns into more complex and difficult ones. Here again we have been guided by the belief that it is in such re-combinations of simple movements that the crux of the apraxic child's difficulty rests" (p. 191).

"It is common to assume that the simple, largely reflex patterns of movement which enter into walking and running, for example, are sufficiently well acquired by the child without training so that in the more difficult sports, such as tennis, attention need be given only to the special instruction for that game and this, of course, is true of most children. In those with a measure of apraxia in their make-up, however, this assumption is not justified and much better headway might be made by spending some time teaching the child how to run and turn and stop without losing balance, before specific training in the sport is begun" (p.192).

Today it is obvious that learning difficulties are not to do with whether one is intelligent or not but it is very likely that many children have been and still are being misunderstood. Annell (1949) described in an article a group of children with motor dysfunction. In a cohort of 600 children aged 6 to 17 yrs, either in the ward or out-patients of the Department of Child Psychiatry in Uppsala, Sweden, 78 children (61 boys and 17 girls) or 13\% had motor dysfunctions. Of these children, 57 (47 boys and 10 girls) had an average or above average I.Q. Besides having difficulties in ordinary life activities (things such as threading needles, eating without spilling and doing up buttons) they often had a history of late speech development. The children briefly described in these vignettes (Annell, 1949) are recognizable even today.

"Briefly, this 8-year old boy had the physical development of an 8-year-old, the speech development of a 14-year-old and the motor development of a 5-year-old. In his class at school he is in some respects far ahead of his class mates, but as regards motor activities he is far behind them and has no normal contact with them. He tries, when such subjects are studied in school in which his motor retardation is apparent, to compensate his weakness by clowning or by distracting interest from the work he is to do" (pp.906-907). 
"A boy, aged 14, with an IQ of 139, had during the past year the lowest marks in all written subjects and gymnastics, low marks for conduct since, amongst other things, his exercise books were always full of ink-blots, etc., that it was considered due to carelessness. He showed an intense dislike of school and wanted to be a farmer. /His movements were slow, he wrote slowly and unevenly, and did up buttons slowly. He found it difficult to carry out any movements that could not be controlled visually, and could not walk on a strait line on the floor with his eyes shut" (p.907).

Under the heading 'Clumsy Children', an editorial in British Medical Journal (1962) did a follow up of Anna-Lisa Annell's article. The editor compared her observations with more recent research and concluded that clumsy children are not uncommon and, "The worst thing we can do is to call him naughty when he has a physical handicap" (p.1666).

In his book 'Reading and remedial education' (1967), the British educator A.E Tansley claimed that possible damage to the nervous system existed among children with reading and writing difficulties. A 'softer' formulation would be that there could be a physiological origin to their problems. Tansley emphasized the importance of reading readiness. Teachers, he argued, are often too anxious about getting a child to read and might push him before he is ready. It is therefore important that teachers and parents are trained to see signs of readiness. The child should have a readiness in (1) language development, (2) physical and sensory development and in (3) emotional and social development. In his book he outlined a 'remedial' treatment of a child's inability. He preferred the term 'remedial' because the treatment given is psychological, educational, social and medical relating to a scientific diagnosis of the reading disability. As the field of learning disabilities slowly grew, Ozer (1968) found it necessary to put forward the need for a more accurate neurological examination of the child with learning disabilities. This examination did not only focus on motor function, but also compared the child's brain function to its learning capacity. Still in the 1970s, when the first generation of youngsters diagnosed as learning disabled grew up (Orenstein, 2000), a true science of learning disorders seemed unreachable (Pennington, 2009).

However, Chruickshank (1981) suggested a novel perspective for teacher training and proposed the 'Neuroeducator'. Thirty years later though, as far as I know, only the University of Portland, School of Education, Oregon, USA is offering courses and a Postmaster Certification in 'Neuroeducator'. The requirements set by Chruickshank were (1) an understanding of human anatomy, (2) a solid understanding of human neurology and neurophysiology, (3) a basic understanding of intelligence, (4) a basic understanding of perception and the psychology of learning, (5) an understanding of movement education and an understanding of (6) speech communication. He also required the student's ability to communicate the child's problem accurately to its parents. Mycklebust added in his article 'Toward a Science of Learning Disabilities' (1983) that the evolving definition would come to include references to both verbal and non verbal learning and concluded; "A science of learning disabilities is forthcoming".

\subsection{The present situation}

Today, different kinds of learning disabilities constitute a serious, worldwide problem. About $10 \%$ of school-age children are affected (Levin, 2003) and Orenstein (2000) estimates that as many as $20 \%$ of adults suffer from different kinds of Undiagnosed Learning 
Disabilities (ULD). Using the broader term 'learning disorders' (Pennington, 2009) to connote "any neurodevelopmental disorder that interferes with the learning of academic and/or social skills" (p.3), Pennington reviewed Dyslexia, Speech and Language Disorders, Autism Spectrum Disorder, Attention Deficit Hyperactivity Disorder (ADHD), Intellectual Disability, Developmental Coordination Disorder (DCD), Mathematics Disorder and Nonverbal Learning Disorder.

ADHD is recognized as a functional deficit that affects approximately $5 \%$ of the global population (Polanczyk, de Lima, Horta, Biederman \& Rohde, 2007) and many children diagnosed with ADHD are described as awkward or clumsy. They exhibit motor-perceptual difficulties (Yochman, Ornoy \& Parusch, 2006) and match the criteria of DCD (Feng, Cheng \& Wang, 2007; APA, 1994). A Swedish study (Kadesjö \& Gillberg, 1998) showed that almost $50 \%$ of the children matching the full criteria for ADHD (DSM-III-R), also matched the criteria for DCD. Gillberg (2010) has recently pointed out that within this field, the coexistence of disorders is a rule rather than an exception. Largely, DCD is equivalent to what was previously called 'Clumsy Child Syndrome' and refers to children whose motor development is delayed irregardless of whether neurological causes are evident. Between 5 and $9 \%$ of all school children are affected (Cairney, Hay, Wade, Faught, \& Flouris, 2006). Learning disabilities and emotional immaturity become more apparent over time, and as adolescents these children evince social, emotional, and academic difficulties to a greater extent than others. They also run a higher risk of starting to use alcohol (Rasmussen \& Gillberg, 2000) and according to Levin (2003), 10\% of adult psychiatric patients suffer from learning disabilities. In her book 'Smart but stuck', Myrna Orenstein (2000) uses the concept 'imprisoned intelligence' in the sense that ULD can cause feelings of shame because of the inability to fully achieve academically and the constant feeling of being inferior. Although in some circumstances shame can serve a positive purpose, for children and adults with learning disabilities who never fully succeed the outcome is negative. As another consequence of learning disabilities, whether diagnosed or undiagnosed, shame is of great importance not least because together with guilt, they are both (Nathanson, 1994) symptoms within the field of depression. Polatajko (1999) writes about low self-esteem and secondary emotional or behavioral problems in relation to children's motor problems. There is some evidence to show that a consequence of DCD may be internal disorders (De Raeymaeker, 2006; Cairney, Veldhuizen, \& Szatmari, 2010) and still another consequence of DCD (Faught, Hay, Cairney, \& Flouris, 2005) is an increased risk of coronary and vascular disease. Although it is likely that the DCD spectrum includes thin and energetic individuals as well as those who are more or less obese and less mobile, it is the latter who are probably more at risk. This view is proposed in three articles published in economyorientated journals.

According to Lundberg, Nystedt and Rooth (2011) there is a correlation between obesity during adolescence and wages later on in life. Of equal importance, the reasons seem to be on one hand family habits during childhood and on the other hand low physical fitness and a lower non-cognitive ability. Non-cognitive abilities are described as being self confidence, ability to interact and cooperate, motivation, time preferences and endurance. Lindqvist and Vestman (2011) confirmed in their study that non-cognitive abilities, as measured above, were as important as cognitive abilities in their impact upon salary levels. Lundberg et al. (2011) explain that non-cognitive abilities and obesity have only recently been correlated 
and that the connection is sociological rather than biological. In their example, a correlation between obesity and non-cognitive inabilities might follow if a child is excluded from sports and social activities. Cawley and Spiess (2008) claim to have identified such a connection among children aged only 2-3 years. Although a sociological explanation seems good enough, from my point of view, it is equally likely that it might be the other way around. A child who is unable or finds it uncomfortable to move is more likely to remain outside of social fellowship. Interestingly, Lundberg et al. (2011) conclude that although there is a correlation between obesity, non-cognitive abilities and wages there might also be other underlying, not yet considered variables affecting all three. Such variables could be parental characteristics or aspects of up-bringing, equally affecting all siblings. I will return to this in the discussion below.

Generally, learning disabilities are thought about and labeled as cognitive and, accordingly, special education seems to aim at teaching children strategies to overcome their problems, which is of benefit to some. For others, however, the difficulties more or less remain and we have to ask why this is the case. Are there factors which up until now have not properly been considered? If so, what could they be?

During the last centuries, focus on cognition, teaching, information and instruction has increased. The importance of early learning is a mantra within both politics and science, and parents are instructed how to begin to teach their children as early as possible. At the same time, more children are less mobile and less time is spent playing spontaneously. Is there a too strong belief today that what comes from the outside i.e., in teaching, information, and instruction goes in? I don't have the answer but I would like to counterbalance with a reintroduction of the concept 'education' and suggest a complementary approach. Throughout history (Arendt, 2006, Furedi, 2009, Ecclestone \& Hayes, 2009) and up to the present day, the schooling of children has been a matter of values and also a matter of emphasizing education, learning or training depending on the aim of the schooling and the basic assumption of what a child really is. Arendt (2006) writes; "To educate, in the words of Polybius, was simply 'to let you see that you are altogether worthy of your ancestors' " (p.191).

\subsection{A complementary approach}

The word 'education' is etymologically derived from the Latin word e-duco meaning 'bring out' and suggests according to Kegan (1994) "a 'leading out from' ". My view is in line with Kegan's who writes that the focus of information is to change what people know while "education leads us out of or liberates us from one construction or organization of mind in favor of a larger one" (p.164). This might be very close to what Watzlawick, Weakland, and Fish (1974) and Ahrenfelt (2001) define as a first-order change as opposed to a second-order change. A first-order change (Watzlawick et al., 1974) follows a 'more of the same' strategy based on common sense. It will be a 'renewal' of what is already there (Ahrenfelt, 2001). On the other hand a "second-order change usually appears weird, unexpected, and uncommonsensical; there is a puzzling, paradoxical element in the process of change" (p.83) and there is a change of the whole system (Ahrenfelt, 2001).

My first assumption, which is connected to information, is that many of the remedial teaching methods used today might create changes which are more of a first-order. 
My second assumption, which is connected to education, is that change is possible from within and that such change is of a second-order.

My third assumption is that information and education are complementary and that a pedagogical challenge will be to evaluate how they can counterbalance each other according to the special needs of the child.

My fourth assumption is that it might be possible that learning disabilities to a higher degree than previously realized are due to sensorimotor immaturity.

\section{Background}

\subsection{Developmental coordination disorder. Old problems but a new label}

The vignettes, above, from Binet and Simon (Strauss \& Lehtinen, 1947), Orton (1937) and Annell (1949) show that the sensorimotor and concentration problems we face today among children and adolescents are far from new. It is obvious that sensorimotor difficulties have been a documented companion to mental retardation as well as to learning disorders throughout the last century. What is now labeled DCD (Pennington, 2000) has previously been recognized under different names such as 'motor deficiency', 'congenital maladroitness', and 'minimal brain dysfunction'. As a motor skills disorder, DCD is described as follows in DSM-IV (American Psychiatric Association, 1994);

"The essential feature of Developmental Coordination Disorder is a marked impairment in the development of motor coordination (Criterion A). The diagnosis is made only if this impairment significantly interferes with academic achievement or activities of daily living (Criterion B). The diagnosis is made if the coordination difficulties are not due to a general medical condition (e.g., cerebral palsy, hemiplegia, or muscular dystrophy) and the criteria are not met for Pervasive Developmental Disorder (Criterion C). If Mental Retardation is present, the motor difficulties are in excess of those usually associated with it (Criterion D). The manifestations of this disorder vary with age and development. For example, younger children may display clumsiness and delays in achieving developmental motor milestones (e.g., walking, crawling, sitting, tying shoelaces, buttoning shirts, zipping pants). Older children may display difficulties with the motor aspects of assembling puzzles, building models, playing ball, and printing or handwriting" (pp.53-54).

It is a pity that still, after at least 100 years, we lack sufficient methods to help those affected.

One reason might be that for a long time the child was supposed to 'out-grow' his problems.

Another reason might be a lack of consensus. As mentioned above, because of the difficulty of measuring the appropriate index, problems organic in nature might be diagnosed as functional, and vice versa. Gillberg and Kadesjö (2009) give the example of Attention Deficit Disorders (ADDs) and DCD. DCD and motor clumsiness are traditionally considered to be within the territory of a child neurologist or a developmental pediatrician while ADDs, including ADHD, typically fall within the domain of child psychiatry and psychology. "This 'split' may explain the fact that few psychiatrists are aware of the implications of the motor and perceptual problems that are so often comorbid with childhood ADHD. Conversely, child neurologists often fail to appreciate the effect of attention deficits on the lives of the clumsy children whom they see for diagnosis and workup" (p.305). 
A third reason might be the fact that no method, so far, has proved to be effective enough. Several longitudinal studies of DCD (Polatajko, 1999) show that motor problems persist and that other parts of the child's development are affected. Meanwhile a lot of research concerning diagnoses and conceptual issues has been published while few, if any, (Polatajko, Rodger, Dhillon, \& Hirji, 2004) cohesive training methods have been developed, evaluated and used. Polatjko et al. (2004) end their review by stressing the importance and need for rigorous research to explore methods of treatment suitable for DCD. The method Retraining for Balance, to be presented below, is a new strong candidate which in initial studies (Niklasson, Niklasson, \& Norlander, 2009; 2010) has shown not only promising results but also has opened up a novel perspective on sensorimotor training. This novel perspective might give us a hint as to why previous methods have failed to break through. I will tentatively discuss this below.

To conclude; for progress to be possible, there has to be, not only an extended co-operation between different faculties but also a recognition from the scientific community of the need for the development and evaluation of therapy methods.

Coming from the field of education, I have written this chapter in dialogue with representatives from two other fields of science, child neurology and psychology, each with its special interest in the wellbeing of the child. One has argued elsewhere for an early screening and detection of ADHD and DCD (Rasmussen \& Gillberg, 2000) not least since coexistence (comorbidity) means that poor psychosocial functioning is very likely. Two of us have previously (Niklasson, et al., 2009; 2010) evaluated a method for sensorimotor therapy, Retraining for Balance. Together we have published (Niklasson, Rasmussen, \& Norlander, 2010) a call for the importance of further studies. At this time there exists no standardized manual for the testing of primitive/primary reflexes in older children and adolescents. Therefore, we have recently started such a study.

\subsection{Different approaches to sensorimotor training}

Techniques used in formalized sensorimotor training differ both from a theoretical and a methodological perspective. Pless (2001) makes a distinction between General Abilities Approach (GAA), Sensory Integration Approach (SIA) and Special Skills Approach (SSA). The GAA proposes that age-appropriate reflexes, postural reactions, and perceptuomotor proficiency form the basis of functional motor ability and the development of thought processes. The SIA stresses vestibular stimulation and suggests that sensory integration might be the basis for language, motor and intellectual development. According to the SSA, finally, more sophisticated motor skills are formed by specific motor learning.

\subsection{Retraining for balance - An introduction}

The method Retraining for Balance (RB) can be considered as a mixture between the approaches of GAA and SIA. The concepts of primary reflexes and postural reactions are borrowed from GAA while the theoretical foundation of vestibular stimulation is borrowed from SIA. The basic GAA perspective, theoretically and practically used in RB was developed by Peter Blythe (Goddard Blythe, 2009) at the Institute for Neuro-Physiological Psychology (INPP) in Chester, Great Britain. Peter Blythe and Sally Goddard Blythe have over the last 20 years very successfully spread their work globally and a lot of practitioners 
are using their method. Although Blythe stresses the importance of vestibular stimulation (Vose, 1986), it is the ground breaking work of Jean Ayres (1973) which is to be regarded as foremost in the SIA approach.

In the early 1990s, the INPP- guidelines for how to carry out assessments (Goddard, 1990) and use exercises were strictly mechanical and linear. The meaning being, that when through assessment you identified certain immaturities (to be explained below) you were supposed to use certain exercises in a 'goal directed' way. This meant that some children went through training using just a few exercises while others had to use more exercises and the duration and content became rather different from child to child. Vestibularis, a private practice in Sweden, was not satisfied with the results achieved whilst working in this way. It had noticed that some exercises seemed more powerful than others and this inspired the attempt to create a harmonious totality of the different movements (Niklasson, Niklasson, \& Bergström, 1999, 2007). To put it 'poetically', something more like soft and round rather than sharp and strait. Vestibularis' modification or rather re-construction was named 'Retraining for Balance' and aimed at forming a method with a common start and end and with a sense of cohesion between exercises. The re-construction and further development was influenced by theories from research carried out by the Finish brain neurophysiologist and physicist Matti Bergström, who also took an active part as an advisor. Bergström had previously suggested $(1967,1972,1989)$ that, "The psychological state is a macrostate of the same system of which the physical state is a microstate" (1989, p. 130). Coming from another angle, Paul Schilder (1886-1940) much earlier appears to be "the first psychiatrist to view the human psyche as a physical phenomenon" (Hubbard, \& Wright, 1984). This was also what empirically became obvious during training when different movement patterns seemed to affect behavior in different ways. I will return to this below.

\subsection{Primitive reflexes and neurological soft signs}

Among psychologists, the 'reflex' is recognized as a basic aspect of physiological psychology (Clarke, \& Jacyna, 1987) and given a certain status. Although the papillary reflex (Flugel, 1933) was observed by Galen (A.D 129-199) and the word 'reflex' was used by Jean Astruc (1684-1766) the concept did not reach widespread recognition until the substantive 'the reflex' (Clarke, \& Jacyna, 1987) was coined by Marshall Hall in 1833 and used in a biological and purely mechanical sense. Through his research on decapitated animals (Flugel, 1933) he had observed that by proper stimulation certain kinds of bodily movements were elicited with the help of the spinal cord and the peripheral nerves. These movements were independent of the brain and therefore had another character compared to voluntary and conscious movements. One of the first to document the development of infant reflexes from birth and beyond, through experience and learning, was W. Preyer (1841-1897) a pioneer in the science of child psychology. Preyer who was a physiologist born in England and working in Germany published 'Die Seele des Kindes' (On the Soul of the Child) in 1882.

The concept 'neurological soft signs' (NSS) (Ayd jr, 2000) is used to describe neurological aberrations not believed to constitute well-defined neurological disturbances. Because they are difficult to localize, NSS might sometimes be considered as reflecting a diffuse brain dysfunction, but they nonetheless are frequent among youths with hyperactivity and emotional disorders. According to Mitchell (2003), NSS are of importance because they are rarely present in healthy controls. There is no standard list of NSS but the concept includes 
retained primitive reflexes (grasp, snout and sucking), a deficit in sensory integration and subtle deficits in sequencing of complex motor functions and in motor coordination. Children diagnosed with DCD (Polatajko, 1999) don't show any clear-cut evidence of neuropathology or neurological 'hard' signs but they might show 'soft' neurological signs.

\subsection{Semantics and concepts}

As neonates (Illingworth, 1987) we were all equipped with about 70 brainstem mediated primitive (primary) reflexes, some of which were closely connected to the vestibular system. To begin with these reflexes were like a 'survival kit' and easy to elicit. During the first year of life (Capute, \& Accardo, 1991) as the nervous system matured and voluntary motor activity emerged they became more difficult to elicit. These early reflexes (Chrutchfield, \& Barnes, 1993) are traditionally called 'primitive' either because they are thought not to persist throughout life or "because the infant's brain is considered to be a primitiveunderdeveloped, incompetent, deficient- edition of the adult brain" (Touwen, 1984 p.115). There are, however, some controversies surrounding the concept which are worth mentioning.

First, Touwen (1984) argues that neither the concept 'primitive' nor the concept 'reflex' are appropriate;

"In a conception of the developing brain which emphasizes the involvement of the whole system in all changes during development, and that considers the healthy infant's brain as an age-specific and age-adequate organ system, it is no longer valid to use the term 'primitive reflexes'. The word 'primitive' is simply inadequate. Purely stereotyped reflexes do not occur, although reflex mechanisms may be hidden by the variable display of the infant's complex brain. Reflexes and reactions, and their developmental course, are useful in the neurological examination of infants but their existence in itself is not an adequate explanation of how the brain works" (pp. 122-123).

I agree with Touwen when he writes (p.120) that the concept used mirrors ones view of the developing brain. In line with his discussion, with Bergström $(1972,1989)$ and also with Gesell (1988) we have used the concept 'behavioral movement patterns' as a complementary term (Niklasson, et al., 2009). Other authors, for example McPhillips, Hepper, and Mulhem (2000), use the term 'primary reflexes' while French authors such as Mehler and Dupoux (1994) use 'archaic'.

Second, there is a controversy as to whether,' the reflexes' persist throughout life or not. Paulsen and Gottlieb (1968) state "Senile and presenile patients who are demented may show several responses which can be called developmental, foetal or primitive reflexes. These responses are normally present during the early maturation of the central nervous system and they may reappear when the central nervous system has been altered by age and disease" (p.37). "The initial background from which the primitive reflex arose apparently still remains, and any foetal reflex responses may reappear whenever higher controls are weakened" (p.50). This view is shared by Teitelbaum (1967) who finds it obvious that the reflexes remain within the nervous system but as Jean Ayres (1973) concludes "the degree to which a person suppresses or attains mastery over them usually reflects the degree of maturation and integration of postural mechanisms" (p.80). A possible 
regression to lower level brain activity when higher levels are impaired, resulting in primitive motor behavior is suggested by Bergström (1963). Jacobs and Gossman (1980) investigated certain primitive reflexes and found them active in healthy adults. So did van Boxtel, Bosma, Jolles, and Vreeling (2006) who found their increased prevalence with age but that their presence could not be a marker of cognitive decline. Touwen (1984) on the other hand, considered the morphological difference between the adult's brain and the infant's brain. Emphasizing their different functions, he argued that the adult's ageing brain and the infant's healthy brain cannot possibly display identical mechanisms. Although I agree with Touwen's semantic objections, sensorimotor training according to RB is based upon the concept of the possible life long persistence of 'behavioral movement patterns'. However, in order for me to be consistent with most literature I will use the concepts primitive/primary reflexes until my conclusion.

\subsection{Primitive reflex inhibition and the emergence of postural reactions and gross motor milestones}

As primitive/primary reflexes are inhibited during the first year of life postural (bodyrighting) reactions (Morrison, 1985; Capute, \& Accardo, 1991) as well as gross motor milestones such as rolling, creeping (locomotion in prone), and crawling (quadrupedal locomotion) appear. Gross motor milestones generally emerge during the 6th to 12th month. This is also one of the intervals when the vestibular system is most sensitive and receptive to stimulation (Ornitz, 1983). During the period when the child is creeping and crawling (Maurer \& Maurer, 1989) it is also very likely that a more mature sense of balance develops.

\subsection{The common sense and the vestibular system}

The vestibular system can easily be seen purely anatomically, as just what it is, a part of the inner ear, physiologically responsible for balance, the detection of movement and closely connected to hearing but not recognized as one of our basic senses. As the main purpose of this chapter is an attempt to connect its physiological function with psychology and behavior, I shall leave it to the reader to consult any book in basic neuroscience in order to learn more about the structure and mechanics of the vestibular system, e.g. Guyton (1991).

The vestibular system is different from other senses not least because experiences after stimulation are not specifically located as they are with other senses. Wade (2009) explains, "we feel giddy or see the world spin rather than have a single sensation like sight or hearing" (p.79). One of the first to study its psychological implications was Paul Schilder who wrote (1942), "Organic changes in the vestibular apparatus will be reflected in the psychic structures. They will not only influence the tone, the vegetative system, and the attitudes of the body, but they must also change our whole perceptive apparatus and even our consciousness. These general considerations make it possible that the study of the vestibular apparatus may have great importance for the understanding of psychotic and neurotic states"(p.85).

Even before Aristotle (ca. 384-322 B.C), Greek philosophers discussed and described perception, much of which was collected by Theophrastus (ca. 370-286 B.C.) (Stratton, 1917). The senses, as analyzed by Aristotle himself (Heller-Roazen, 2007), were sight, hearing, smell, taste and touch and to each he added a corresponding proper object, characteristic 
medium and particular organ. Among the senses he considered touch to be primary. I will return to Aristotle and the senses below but first let me take a leap forward in history.

In the late 18th century (Finger, 1994, Wade, 2009), observations gave empirical support for a separation of a muscle sense from touch. The British neurologist Henry Charlton Bastian (1837-1915) who was a devoted researcher on this muscle sense believed that information, necessary for the brain's coordination of motor acts, was provided by the muscles. In 1880 he coined the term 'kinaesthetic' a concept replaced in 1906 by Sherrington's term 'proprioceptive'.

The late 18th and early 19th centuries were very active and fruitful years for physiological research. Although giddiness and vertigo (Wade, 2009) had been well known phenomena described mostly in medical terms since ancient times it took a long time for science to connect the feelings to the vestibular system. By 1765, Robert Whytt included vertigo among the symptoms caused by nervous diseases. In 1803, Bell discussed diseases of the inner ear documenting that an inflammation around the auditory nerve also gave an increased sensitivity for vertigo but concluded "Of the diseases of the labyrinth, there is little on the record" (p.71). The gross anatomy of the labyrinth was known but its function was not understood. Through the interest in vertigo, the vestibular system was obviously investigated indirectly. William Charles Wells (1757-1817) who carried out research on postrotational vertigo and nystagmus was later to be recognized as the first to give "...the first clear behavioral evidence for the vestibular sense" (p.75). Theoretically, he also understood that some neurological system must register the body's position in relation to gravity but he never came up with an answer. The answer was provided in the 20th century when the electron microscope was invented and scientists were able to identify hair cells in the cochlea and later in the vestibular system. By habit or tradition the senses had been studied separately and it was not until the 1960s (Berthoz, 2000) that physiologists realized the importance of studying the combining of sensations. In the light of history this is strange especially as Aristotle once wrote (Berthoz, 2000),

"We perceive things as a whole, rather than what some may refer to as a continuity of their parts. Yet we can say that things do not always appear to us as they are; and that is why the size of the sun as we see it is not its true size. But let us return to our earlier question, whether we can perceive several things simultaneously, that is, in a single part of the soul, in an indivisible moment. It has been proved that the soul perceives all sensations with one and the same faculty, which collects the information from all the senses. Yet this faculty, though numerically one, differs in its accounts: it is the same soul, but differently disposed" (pp 57-58).

In 'De Anima', 'On the soul', (Aristotle, 1992) book II and III, Aristotle discusses the senses and concludes that there could not be more than five. Yet, he argues, each sense is not enough to explain the totality of sensory experience and proposes the perceptual phenomena 'common sensibles'. "'Common sensibles' are movement, rest, number, figure, magnitude; these are at any rate certain kinds of movement which are perceptible by touch and by sight" (book II, ch.6).

In book III, chapter 1 he advises, as interpreted by Alexander of Aphrodisias, (HellerRoazen, 2007) that "There Is Something with which We Sense Everything Simultaneously" (p.48). Throughout history the term has been used and discussed within Greek, Arabic and 
Latin scholastic traditions. Thomas Aquinas wrote in 'Commentaria in Aristotelem' "it is by the common sense that we perceive that we are living" (p.162). Another man of the church, Jean d'Arckel (1314-1378) is ascribed with saying "The common sense is a power that embraces all proper things that affect the proper senses...We thus say that the common sense is the fountain and the source of all the individual senses, to which all sensible movement is brought back, as to its ultimate end...Some locate this capacity in the back of the brain, where the nerves of the five senses meet; others place it in the heart, since it is the fountain and the source of life" (pp.160-161). Returning to the 18th century (Clarke \& Jacyna, 1987) and to Jiri Procháska (1749-1820), most famous for his publications about the reflex but also interested in 'sensorium commune', which for him was the place where the sensory impression turned into a motor message which activated the muscle. He proposed 'sensorium commune' to be located in the brain stem, spinal cord, cerebellum and thalamus. Consulting 'The Oxford Companion to the Mind' (2004) for an up to date definition of 'common sense' it says, "The original meaning is a 'common centre' or neural pool, into which all the five senses were supposed to contribute to give coherent perceptions, though the various senses are so very different" (p.193). From my point of view it is very tempting to think in terms of the vestibular system, knowing also that Schilder (1933) described the vestibular apparatus as a coordinating system for sensory functions, "The vestibular apparatus is an organ the function of which is directed against the isolation of the diverse functions of the body"(p.161). This is an opinion also held by Ayres (1973) who emphasized the importance of the functional integration of the senses. Could it be that Aristotle, the scholars and even the physiologists of the 18th century were intuitive forerunners to the discovery of the function of the vestibular system? Although Aristotle declares firmly that there is no sixth sense, he states that all form a unity through incidental perception (book III, ch.1). Over the centuries we have seen a slight movement from his original writing towards the essence of the vestibular system as it is understood today, especially with its closeness to proprioception and to the reticular formation. It is not unlikely that they, in their time, were closer to nature than we are today. However, none seems to have come up with a suggestion as to what makes the 'common sense' able to combine different perceptions in to a coherent one. The vestibular system together with the reticular formation (Guyton, 1991) and the proprioceptive system (Brodal, 1960, 2004; Robbins, 1977) appear to be good candidates for an integrating system as impulses from the five senses and from muscle joints are directly and indirectly received by vestibular nuclei. But which factor might be the integrating factor?

\subsection{The gravitational force}

Turning to Bergström (1997) the answer is the gravitational force;

"We have to proceed from the premise that the human brain belongs to nature instead of being separated from it. This means, for us to understand child development and play, we must presume nature to be a larger system containing the brain as a smaller system which is influenced by incoming and outgoing information" (p.22).

He continues with a description of how the proprioceptors are driven by the gravitational force and how this force is a precondition for a proper brain stem function and for consciousness. "We can now understand that consciousness is basically transformed gravitation, thus being a 'planetary' quality bound to matter"(p.25). (These citations are translated from Swedish. For another summary in English, see Bergström, 1989). 
In a scientific context it might seem a bit odd to write about us humans in a universal perspective but it is not only Bergström who holds this view. Further east, V.I Hasnulin, member of the Russian Academy of Medical Sciences Siberian Branch, wrote in a monograph (2004), "Every particle of a human body, as of any other material object is connected simultaneously by means of gravity with all the bodies in the Universe" (p.33).

Appearing nine weeks after conception, the vestibular nuclei are functional by the eleventh week (Humphrey, 1965). At about the 21 ${ }^{\text {st }}$ week (Robbins, 1977; Larsen, 1993), aside from the interoceptive sensory receptors (sensory receptors in the walls of the thoracic, abdominal, and pelvic viscera), the vestibular system is the only sensory system which is mature. Although developed this early, some authors (Windle, 1971; Prechtl, 1984) believe that the system is inhibited during prenatal life. Others like Odent (1986) and Restak (1979) claim that the floating fetus is constantly stimulated by the mother's movements and registers its first perceptions through the vestibular system. It is because of this early maturation that the vestibular system is so important for brain development and "a disturbance of its function by any factor will be reflected in the formation of the whole nervous system" (Klosovskii, 1963, p. 116)). In favour of the proposition that the fetus reacts to the gravitational force (Hubbard, \& Wright, 1984, Eliot, 2000) is the turning of its head into the head-down position weeks or days before birth. The first scientific evidence that the early development of the vestibular system is dependant upon gravitational stimulus was provided by a study (Ronca, \& Alberts, 2000) on pregnant rats flown on the Space Shuttle. The rats, developed in space, had a limited sense of balance after delivery on earth. The study showed that the vestibular system needs the gravitational force to mature correctly. Meanwhile the British journal 'New Scientist' (MacKenzie, 2000) reported on a study involving a chemical reaction and the gravitational force. Initially, physicists insisted that the research was not worth doing because the force of gravitation on molecules was presumed to be too weak to affect chemical reactions, compared to other forces. However, the study (Papaseit, Pochon, \& Tabony, 2000) was completed and results showed how gravitation had indeed influenced chemical reactions on the cellular level. The scientists studied microtubules, fibers made of a protein called tubulin. When cold solutions of mammalian tubulin mixed with GTP (an energy releasing compound) were adjusted to body temperature for a certain time, distinct bands of microtubules were formed at right angles to gravity. When the procedure was repeated in microgravity the bands pointed in all directions. This spontaneous generation of patterns in a chemical reaction, due to tiny environmental asymmetries, was the first experimental model of biological selforganization. The result had previously been predicted by the biophysicist Ilya Prigogine and by Alan Turing in the 1950s. I will return to Prigogine's research below.

\subsection{Music of the spheres}

Gravitation (Rees, 2000) is the most perplexing of the basic forces of nature and still today is a mystery. The force is so fundamental that if we should start anew with intelligent life on another planet we would have to start with gravitation. As gravitation is always an attraction it is the organizing force for the cosmos. Even Isaac Newton (1642-1727) had difficulties understanding what gravitation really is. Just the scientific, mechanical explanation did not seem to satisfy him. It is said that he regarded Pythagoras' (569-475 BC) concept 'music of the spheres' as a metaphor for the law of gravitation. Although (Torretti, 1999) Newton's most celebrated scientific achievement is the discovery of universal 
gravitation he also communicated a spiritual side. In General Scholium, an appendix to the second edition of 'Principia' (1726, p.528), he writes that God "endures forever, and is everywhere present; and, by existing always and everywhere, he constitutes time and space".

As healthy humans we take an upright position for granted although defying the gravitational force is a life long struggle. Very soon after birth the infant starts to lift his head up against gravitation. According to Paul Schilder (Hubbard \& Wright, 1984) it will take the growing child about 15 years to master the force. However, this struggle might have its rewards as Lin, Woolacott and Jensen (2004) showed that postural control among elderly people was not only linked to age but correlated with functional balance as well. In another study (Carpenter, Adkin, Brawley, \& Frank, 2006) it was examined how young adults and older adults with balance problems reacted when balance demands increased. In both groups, increased demands affected both blood pressure, anxiety, and the capacity to handle the body. At the beginning of the 20th century, Joel E. Goldthwait (Goldthwait, Brown, Swaim, \& Kuhns, 1937; Oschman, 2000) and his colleagues at Harvard Medical School were trying to attract scientific attention with their research on patients with various chronic disorders all of which were due to faulty 'Body Mechanics'. Goldthwaith stressed the importance of people paying attention to how they moved and held their bodies in relation to gravitation. If posture was correct more energy would be left for use in daily activities and less strain would be put on different body parts and joints. An incorrect posture would be likely to also have unhealthy effects on the viscera of both the thorax and the abdomen. Once again we can hear history speaking to us but unfortunately the trace left from Goldthwait is not to be found within traditional science but has been picked up by movement therapies and modern body work.

In his sequel to 'Zen and the art of motor cycle maintenance', 'Lila-an inquiry into morals', Robert M. Pirsig (1991) wrote:

"The law of gravity, for example, is perhaps the most ruthlessly static pattern of order in the universe. So, correspondingly, there is no single living thing that does not thumb its nose at that law day in and day out. One could show that the degree to which an organism disobeys this law is a measure of its degree of evolution. Thus, while the simple protozoa just barely get around their cilia, earthworms manage to control their distance and direction, birds fly in the sky, and man goes all the way to the moon"(p. 147).

Pirsig suggests that man's bodily struggle against the gravitational force has over time contributed to an intelligence good enough to conquer space and by doing so even gravitation itself. Much focus is presently placed on cognition and cognitive development while our neurological heritage seems to have been neglected or even forgotten when it comes to education. So how do we connect the gravitational force to learning disabilities?

I propose that an important connection between the gravitational force and learning disabilities is the maturation of the vestibular system and the integration of primitive/ primary reflexes.

\subsection{Summary}

So far, you have been provided with an historical background as to how learning disorders in general have been viewed over the centuries. From there, I moved towards DCD and 
sensorimotor problems which made it suitable to discuss some essential features concerning primitive/primary reflexes, the vestibular system and the gravitational force. I will now reconnect to 3.3 and give a brief presentation of assessment and training according to the method RB. For a more thorough description see Niklasson, et al.(2009, 2010).

\section{Retraining for balance}

\subsection{Clients}

Vestibularis is a private practice using the method Retraining for Balance. Clients are mostly children and youngsters with concentration problems and / or learning disorders. Not all of them are considered clumsy by their parents but notwithstanding this, they will display sensorimotor immaturities on our tests. Adults can also benefit from the training and have completed it with very good results - this has included people who were initially suffering from such diffuse pain and fatigue that it was making them unable to work.

\subsection{Instruments of assessment}

The initial assessment uses the instruments (Niklasson, et al., 2009) RB-Physiological Test (Niklasson \& Niklasson, 1999a, 2007a), Retraining for Balance-Orientation and Balance Test (Niklasson \& Niklasson, 1999b, 2007b) and Retraining for Balance-Audiometric test, based on a technique developed by Johansen (1993).

RB-Physiological Test consists of 41 different tests which assess sensorimotor (physiological) proficiency (maturity) of clients in terms of primitive/primary reflexes, postural responses, gross motor milestones, and vestibular ability. The tests are divided into six groups;

1. Primitive/primary reflexes-vestibular stimulation; tonic labyrinthine reflex prone and supine, symmetric tonic neck reflex, tonic labyrinthine reflex in upright position, Schilder's test (asymmetric tonic neck reflex and tonic labyrinthine reflex), asymmetric tonic neck reflex supine, asymmetric tonic neck reflex on all fours (Ayres' test), and the Moro reflex.

2. Primitive/primary reflexes- tactile stimulation; spinal Galant, palmar grasp reflex, rooting reflex, and the suck reflex.

3. Postural reactions; Landau reaction, amphibian reaction prone, segmental rolling reaction, the oculoheadrighting reaction, and the labyrinthine headrighting reaction.

4. Gross motor milestones; rolling, crawling on the stomach, creeping on hands and knees, and skipping.

5. Eye movements; passive horizontal-tracking and active horizontal tracking in three positions (sitting on the floor with legs crossed, sitting on a stool, and in erect position).

6. Sports related gross motor skills; spring jumping, skipping with a rope, bouncing and catching a tennis ball, and tandem walk.

Each test is scored on a quantitative 5-point scale from 0 - 4 (Field \& Blythe, 1989; Niklasson \& Niklasson, 1999a, 2007a).

0: No deviation, 1: Small remainder of a primitive/primary reflex or minor difficulty completing a specific feature, 2: Remainder of a primary reflex or partial absence of a postural response or difficulty completing an item, 3: Almost intact primary reflex or almost 
a total absence of a postural response or a marked difficulty completing a particular item, and 4: Intact primary reflex or a total absence of a postural response or an inability to complete or execute a specific item.

Retraining for Balance-Orientation and Balance Test. This test (Field \& Blythe, 1989; Niklasson \& Niklasson, 1999b, 2007b) consists of a standing balance assessment (Rodnitzky, 1988; Cherng, Chen, \& Su, 2001; Geuze, 2005) done on two occasions (the Romberg test), a vestibular test (rotating on a chair) (Vose, 1986; Guyton, 1991; Niklasson et.al., 1999, 2007), and two tests of orientation (body-space perception, perception of time).

Each test is assessed according to whether there is either "no deviation from normal ageappropriate behavior" or "deviation from normal age-appropriate behavior".

Retraining for Balance-Audiometric test with the aim to determine whether the client has right or left ear dominance or whether dominance is lacking. Right ear dominance facilitates a more rapid processing of speech sounds (Sininger \& Cone-Wesson, 2004). The tests' rationale for importance of right-ear dominance was validated by Tallal, Miller, and Holly Fitch (1993) and by Okamoto, Stracke, Ross, Kakigi, \& Pantev (2007).

\subsection{Training}

The decision as to whether to start the training or not is taken with respect to the scoring on each test and with respect to the child's developmental history as described by its parents. However strange it may sound, low scoring does not necessarily imply that the client would not benefit from the training. This is especially relevant for those older children or adolescents who may be able to compensate for their difficulties. If this is the case, the history as described by parents is of particular interest. When the decision has been made to start the training, the client trains at home with his parents. The fact that the parents themselves are 'solving' a problem together with their child is a methodological asset. An association between the development of movement and emotion has been argued by Schilder $(1964,1971)$ and Erikson (1987) and they also emphasize importance of the parents in this process. The estimated time needed for training is about 15 minutes/day although it often takes longer because of obstinacy which seems to be a part of the regressive behavior which emerges during training. The child with its parents returns to Vestibularis every 8th week for re-assessment and in order to get new exercises. During a re-assessment, appropriate primitive/primary reflexes, postural reactions, vestibular function and gross motor milestones are checked and suitable new exercises are introduced. Generally fifteen sessions are needed to complete the program.

Retraining for Balance -Methods (Niklasson, et al., 1999, 2007) describes 48 exercises which comprise the training and which in many ways are the same as those used at INPP (Goddard, 2002) although modified and in some cases further developed. The exercises are divided into the following seven categories:

1) Fetal movements and neonatal movements 2) Vestibular stimulation 3) Auditory perceptual stimulation 4) Tactile stimulation 5) Basic gross motor movements or milestones 6) Sports-related gross motor skills 7) Complementary play exercises.

For further description of the categories see Niklasson, et.al.,(2009). 
The basic theory behind the training was formulated by Blythe in 1980 (Goddard, 1990), "the innate mechanistic processes involved in the inhibition, modification and transformation are observable, and more importantly are replicable at any age, to assist in the rehabilitation of impairment" (p.12). Goddard (1990) continues, “... it is possible to give the brain a second chance to register the inhibitory movement patterns which should have been made at the appropriate stage of development, or, to recapitulate a stage of development which may have been omitted, or incompletely worked through, for one reason or another, during intra-uterine life or infancy. The remediation of aberrant reflexes is based on the primary concept of replication, together with three concomitant theories:

1. Every reflex has a purpose, and will not be fully suppressed unless it has successfully completed the job it was designed to do.

2. All human babies make certain stereotyped movements during the first year of life, (Thelan, 1979). These movements contain within them the natural antedote to the appropriate reflex at that stage in development, thus facilitating inhibition of a primitive reflex on the one hand, and the subsequent release of a postural reflex on the other, together with continued CNS development...

3. There is a sequence and pattern to reflex inhibition" (pp.12-13).

As explained above, Vestibularis had identified a need to bring coherence and continuity to the different exercises. One reason for this was that different physiological and psychological regressions emerged when certain exercises and vestibular stimulation were used, a phenomenon not mentioned by Blythe. When an exercise was used long enough the regressions faded and physiological and/or psychological behavior seemed to be transformed to a more mature level. Instead of breaking the apparent 'flow' by being too mechanical, Vestibularis aimed at creating a smooth succession of exercises, thereby achieving a maximal 'squeeze' from each one. Through continuous supervision from Professor Matti Bergström, Vestibularis came to understand the significance of regressions from a developmental point of view. As an expert on the brain and coming from a research tradition with an interest in sensory and motor behavior, Bergström (1964) was well acquainted with the concept. Another reason for the re-construction undertaken by Vestibularis was that vestibular stimulation seemed to be effective with all clients when used as a complement to fetal and neonatal movements. This view was not shared by INPP as Goddard (1990) wrote;

"In certain cases where there is severe impairment in all sensory channels, and this impairment goes beyond the area of dysfunction into suggested damage, vestibular stimulation and rotation appear to open the gateway to further remediation, where formerly nothing else has worked" (p.15).

In a randomized, double-blind, controlled study McPhilips et al. (2000) used stereotypical neonatal movements similar to those developed by INPP, but no vestibular stimulation, on children with specific reading difficulties. After training, the experiment group showed significant results both regarding reflex inhibition and reading improvements. A recent study by Brookes, Tinkler, Nicholson, and Fawcett (2010) concludes "that there is a significant incidence of balance difficulties in children and adults with dyslexia, even for those without comorbid attention deficit". Comparing under achieving children with well performing children, Franco and Panhoca (2008) found a statistically significant relationship between vestibular disorder and learning impairment. 
Empirically, over the years, Vestibularis has experienced very good results practicing a combination of stereotypical movements and vestibular stimulation. As a first step in studying whether RB could be successful as a complement to regular treatment of DCD, Specific Learning Difficulties (SLD), and ADHD, one quantitative naturalistic study and one qualitative study were conducted.

\section{Evaluation}

\subsection{Study I}

The first study (Niklasson, et al., 2009) was quantitative, naturalistic and examined whether sensorimotor therapy utilizing the training program $\mathrm{RB}$, might be an appropriate technique for sensorimotor proficiency. The 232 children (181 boys, 51 girls) whose mean age was 9.3 yr. $(S D=2.7)$, presented with attention and motor difficulties (according to the School Health Care) as explained by their parents before starting training. The children were divided into three groups, i.e., a younger group (7yr. old or younger, $n=65)$, a middle group (8 to $10 \mathrm{yr}$. old $n=91$ ), and an older group (11 yr. old or older, $n=76$ ). The program has seven categories as explained above (4.3). The training period was close to 3 years on average. Analyses in a repeated-measures design indicated significant improvement of sensorimotor skills among the three age groups, but the older children performed better than the others on several tests. There were only a few differences between the sexes. Our conclusion was that RB may be a functional technique for training children and young people with sensorimotor difficulties and might constitute a complement to regular treatment of DCD, Specific Learning Difficulties (SLD), and ADHD, but controlled studies are necessary before more decisive conclusions can be drawn. Therefore, we plan to begin a controlled study in the near future.

\subsection{Study II}

The second study (Niklasson, et al., 2010) was qualitative and aimed at gaining an increased understanding of the effects of sensorimotor therapy, using the training program RB, on the physical and psychological development of children and young people. The records of 8 children who had completed the program were randomly selected from a cohort of 232 with sensorimotor difficulties and concentration problems. The participants, 7 boys and 1 girl, averaged 9 years of age. The Empirical Phenomenological method (the EEP-method, Gunnar Karlsson, 1995) was used for the analysis, which resulted in 29 categories which yielded 3 overarching themes: a) the introduction of sensorimotor exercises, b) regression to earlier sensorimotor and psychological behaviors, and c) transformations in which the sensorimotor and psychological skills of the children matured and developed. The themes formed the kinesthetic-vestibular developmental model illustrating how sensorimotor exercises push the therapy process forward with recurrent regressions being followed by positive developmental phases. The results of the study were generalized to the remaining 224 children in the cohort by comparing each individual's records to the kinesthetic-vestibular model.

\subsection{Summary}

The aim of the training was to enhance physical maturity and sensorimotor development. Initially, the participants struggled with aberrant primitive/primary reflexes, underdeveloped postural reactions and gross motor milestones all of which were a 
hindrance in the learning process. Goddard Blythe (2009) is recommended as a learned companion when it comes to a more detailed description of how these phenomena can affect a child's possibilities at school and in its social life. Our quantitative naturalistic study (Niklasson, et al., 2009) showed a significant increase in the physical and sensorimotor maturity of participants after completion of the training. The findings also suggested that problems of concentration and attention should be viewed as connected to sensorimotor difficulties. After training, participants generally performed better at school in reading, writing and physical education although with some children difficulties with mathematics persisted. Regarding improvements in the area of reading and writing, we suggested that not only is the integration of primitive/primary reflexes of importance but also the maturation of the vestibular system due to there being a close connection (Simon, Aminoff, \& Greenberg, 1989; Goddard, 2002) between the vestibular apparatus and horizontal tracking required for these skills. As a reminder of this chapter's heading, it is of significant interest that physiological improvements in participants were the results of development which had not previously taken place. By this I mean that participants in the study developed as a child would in its early years of life (as explained in 3.6) despite them being much older. Results from the qualitative study (Niklasson, et al., 2010) showed psychological improvements shaped as regressions and transformations. Viewed in the totality of the training, the phenomena (of regressions and transformations) were complementary and were labeled as either negative or positive developments. The study identified three periods of regression (negative developments) all of which were followed by transformations (positive developments). Using the concept 'negative development' for regression does not necessarily imply something bad. In this context and in accordance with Kris (1952) who distinguished a regression where the ego itself is in charge, a 'regression in the service of the ego', we suggested the opposite. Regression and progression (Werner, 1957; Loewald, 1981) are complementary and of great importance concerning both organization on the psychological level and physical development (McGraw, 1995). The qualitative study was able to show, for the first time as far as we know, both physical and psychological regressions and transformations in connection with sensorimotor training. But what might be the driving force?

\section{Emergence}

\subsection{A possible driving force}

In 3.8 we learned that Papaseit, et al. (2000) were advised not to conduct their study because the gravitational force was considered to be too weak to make any physiological difference. Still, they got unexpected results pointing in another direction. When Vestibularis, during training, placed great emphasis upon vestibular stimulation our studies as well showed unexpected results, especially within the psychological domain. My suggestion is that the gravitational force is an important and hitherto neglected factor in human development. Holger Hydén (1961) famous for his research on RNA and memory wrote; "One unchanging stimulus, for example, is the force of gravity, which maintains a high activity in the gravityresponding brain centers throughout the life cycle" (p.33). Before him D. and K. StanleyJones (1960) considered that, "The force of gravity is the most unchanging, and therefore the most reliable physical fact on the surface of the earth, whether by sea or on land or air. It is therefore on the gravity-receptors, with their unchanging response to an unchanging stimulus, 
that the nervous system has come to depend on for an unceasing and therefore reliable source of energy, without which it is unable to perform any part of its function" (p.60).

As mentioned earlier, there is no consensus as to whether the vestibular system is active in utero or not. Nevertheless, the study of fetal movements is of great interest. Life in utero is a preparation for life to come. All fetal movements observed (Prechtl, 1993) in utero have also been observed in the newborn. As long ago as 1885, Preyer was convinced that the fetus moved its legs and arms before the 16th week. He also considered that movements performed by the newborn (Thelen, 2000), were the same as those developed in utero. However right he was, it took almost 100 years to confirm fetal movements during the first trimester (Reinold, 1976). Regarding the movements of the neonate, De Vries, Visser and Prechtl (1984) wrote, "The similarity between prenatal and postnatal patterns of movement is also striking. The only differences are in quality of movement, probably because of the increased influence of gravity after birth" (p.62).

Metaphorically, birth is a transition from one 'planet' to another, from water into air. For nine months the fetus has been held and contained in a restricted and rather secure universe. Being born is said to be the most stressful and dramatic event ever to be experienced, a preparation for life to come. This brings to mind an old cartoon showing twins in the uterus, with one saying to the other, "do you really believe in a life after birth?". During delivery through the birth canal primitive/primary reflexes such as the asymmetric tonic neck reflex (ATNR) and spinal Galant are set to work and the intense squeezing of the body activates the hormone system. The newborn's first cry comes after contact with air (Casaer, 1993; Prechtl, 1993) and it is likely that the increase in oxygen tension switches on the vestibular system which increases muscle tone. For survival it is of importance that sensory trigger mechanisms such as sucking and rooting are activated soon after birth. Common to all infants are also the palmar grasp, plantar and Moro reflexes. These reflexes are old adaptations of the clinging to the mother. The Moro reflex is of significant interest in RB. Although it is supposed to be inhibited by the fourth to sixth month after birth, with most of the clients at Vestibularis it has been retained. Retention of the Moro reflex (Goddard Blythe, 2009) is associated with an increased sensitivity to vestibular stimulation and might affect both emotional behavior and physiological processes. Because the Moro reflex is ontogenetically very old its retention will hinder (ontogenetically) younger primitive/primary reflexes from fulfilling their work as it, practically, will keep these contained. My experience is that a transformed/integrated Moro will not only create a kind of 'body lightness' with increased flexibility and sometimes an 'uncontrolled' joy in the client but will also set (ontogenetically) younger reflexes to work. Essentially, the Moro reflex is purely vestibular and, as such, fundamental when it comes to the baby's relationship to the earth. At birth, the newborn is almost insensitive to external stimuli but a common fear for all is the fear of falling (Hubbard, 1971; Feldenkrais, 1988). David Hubbard (1971) psychiatrist and a consultant at the Medical Center for Federal Prisoners in Springfield, Missouri, states bravely that the fear of falling is so basic that it might as well "serve as a paradigm for all subsequent fears". Paul Schilder (1964) stresses the enormity of the problem and proposes that because of it, the child should be given 'motor help'. He adds, "We may suspect that mere knowledge on the part of the parents will not be sufficient to handle the problems of equilibrium in the child in a correct way. The parents will need, besides their motor equipment and their will to help the child in his motor expression and 
security, an emotional inner balance" (p.183). Schilder demanded a lot from parents and in doing so he may have caused them to feel guilty but we must not forget that these lines were written in the 1940s. In 6.5 I will return to the importance of the child - parent relationship in RB. Gravitational security (Ayres, 1979) is a prerequisite for a good relationship not only to one self but also to other people not the least to one's parents. Elsewhere Jean Ayres writes (1973), “This relationship [child-parent, my bracket] provides one of the most basic forms of physical and emotional security. It is far more primal than relationships with people, but may be somewhat less so than the individual's relationship with his physical body" (p.60). The child's attempt to overcome the gravitational force is the primal struggle during the first years of life but as mentioned above, it will take about fifteen years for the child to master movements in relation to the gravitational force. Despite this effort, once achieved, gravitational security is not a given.

On one hand, a continuous and life long struggle is required to keep the balance which has been gained.

On the other hand, vestibular receptors are tonically active which means that even when the head is at rest they send a continuous stream of neural impulses to the brain. Hubbard (1971) writes about this, the second language of the vestibulum, which he labels as a cryptovestibular speech. This language "is subliminal in intensity, chronic in character, and almost entirely sensed through other organs (i.e., the eye, muscle tone, vagal distribution, and endocrine responses)" (p.232). In this way we are always connected to earth via the gravitational force. Metaphorically, just as the transmission to the cell phone or to the TV-set needs to be as sharp and as clear as possible, we are the same as regards vestibular transmission. My suggestion is that the gravitational force is an important factor when it comes to a child's sensorimotor development. I also propose that there most probably are connections between sensorimotor maturation and learning disorders. If so, empirical evidence has shown that it is never too late to re-educate the nervous system but the right key has to be used.

\subsection{Developmental re-education}

I have tried to explain that aberrant primitive/primary reflexes, probably constitute a hindrance for both physical and psychological development. In the 1880s Pierre Janet (Tallis, 2002) wrote, "in the human mind, nothing ever gets lost" and Feldenkrais (1988) claimed in the 1940s that, "The functions that are fully matured, or nearly so, at birth, remain strictly localised in the organs and in the nervous system" (p.144). When everything is still there, then obviously there is a possibility to un-lock the system to give it a second chance to mature. In 3.6 we briefly described how postural reactions and gross motor milestones emerged as reflexes were inhibited. This happens naturally at one of the times when the vestibular system is most receptive to stimulation. Our two studies (Niklasson, et al., 2009, 2010) support the view that sensorimotor development is an emergent property of this and from the tentative evidence given above we suggest that vestibular stimulation is the key factor. For a possible explanation I have to turn to systems theory and the thermodynamics of non-equilibrium systems. Today it is possible (Nicolis, 1993) to use concepts such as coherence, order and complexity, traditionally used within biology, to describe the behavior of ordinary physical systems as well as living beings. 


\subsection{Emergence and thermodynamics}

According to Woollacott (1993), the development of motility and balance can be viewed as emergent properties. The meaning of the concept emergence is "an apparently spontaneous generation of novel systematic properties that could not be predicted from the properties of components (parts) of a complex system alone" (Konopka, 2007, p.9). This happens because human beings (Scrimali, 2008) are open, very complex and organized systems which perpetually exchange energy, information and matter with the outside world. An open system (Schrödinger, 1992; von Bertalanffy, 1993) is not in equilibrium. Instead it tends actively towards a higher state of order by reducing the entropy (disorder) which by necessity is produced as a consequence of life. The striving of an open system is to reach further and further from equilibrium and therefore when it is able to import more negentropy (ordered information) than the entropy it dissipates the complexity increases. Prigogine and Stengers (1984) wrote "The 'historical' path along which the system evolves as the control parameter grows is characterized by a succession of stable regions where deterministic laws dominate, and of instable ones, near the bifurcation points, where the system can 'choose' between or among more than one possible future" (pp.169-170). In open systems far from equilibrium small effects will be magnified and this holds also for the gravitational force. Prigogine (2003) stated that, "gravitation keeps things going. In thermodynamics, gravitation disturbs equilibrium, you cannot speak about equilibrium including gravitational forces" (p.66). Therefore (Nicolis, 1993), "Gravity should be regarded as a basic organizing factor in the universe mediating the passage from equilibrium to nonequilibrium and enabling in this way microscopic events to manifest themselves at a global scale" (p.330). My suggestion is that the gravitational force is a vital force also in the self-organization of the human nervous system.

\subsection{Self organization}

Mainzer (1994) argues that genes alone cannot fully determine an organism. Selforganization of some kind is involved in each stage of brain development and it is necessary for ontogeny to use the self-organization of neural systems in order to handle their complexity. Referring to Hydén (1961) who rotated experimental animals and found an increased production of RNA in the big vestibular cells, the Deiter's cells, Pribram (1999) wrote that a striking fact regarding neurons is that they produce more RNA than any other cells when stimulated. According to Gottlieb as cited in Dalton and Bergenn (2007), "experimental animals that receive unexpected or unusually enriched early experiences express more complex RNA sequences, indicating a higher level of brain-based DNA activity" (p.107). Hydén himself wrote (1961), “As Stanley-Jones (1960) has pointed out, the sensory receptors of the vestibular apparatus in the inner ear responding to the force of gravity are non-adaptive and are the most important energy source for increased neuronal activity" (p.40). Turning to Gazzaniga (1992) we learn that "Both animal and clinical data together indicate that normal brain development requires a key signal from the environment if normal connections are to occur. This does not mean that brain development is not driven by genetic factors. What it does mean is that the developing brain has evolved in the context of a particular environment" (pp.37-38). This particular environment is the earth and nothing on earth can escape the gravitational force. 


\subsection{Sensorimotor development and irreversibility}

From what I have described, I regard it to be of utmost importance to monitor the newborn's adaptation to earth and to the gravitational force. During the first year of life a stable nervous system should, from my perspective, be built with the gross motor milestones as 'girders'. For this to be realized, the primitive/primary reflexes have to be inhibited in order for postural reactions to develop. Also, in the first years of life, until the nervous system is stable, the child is at risk of losing stages of development which it has reached. This can arise from various kinds of infections of the nervous system and also, for example, from Otitis media. The necessity of paediatric vestibular assessment in various situations is stressed by Nadi and Luxon (2008).

It is the experience of Vestibularis from children and young people coming to it for training, that all of them lack sensorimotor maturation as defined above and that all of them have learning difficulties in one way or another. It is not unusual that they are frustrated and angry and sometimes they have difficulties expressing themselves verbally. Difficulties remembering are also rather common. In 2.3, Ewald Hering and his speculations about an 'organic memory' were mentioned. From the perspective of the vestibular system his ideas might not be as questionable as they have seemed. The British psychoanalyst Christopher Bollas (1987) uses the concept of 'unthought known' as a description of 'prints' of early experiences. How these early sensations are cultivated might determine the long-term memory, so important (Carr, 2010) for a well functioning working memory. The science of thermodynamics (Prigogine \& Stengers, 1984) tells us that both reversible and irreversible processes are possible. Reversible processes are independent of time while irreversible processes are dependent on time.

Training according to RB gives the nervous system a second chance to mature. I interpret, from experience, that as long as the nervous system is unstable, reversible processes are possible and this is one likely reason why we have been able to identify both psychological and physiological regressions during training. From what I have experienced, I actually prefer to use the concepts 'therapy' instead of training and 'behavioral movement patterns' instead of primitive/primary reflexes. In line with Schilder and Bergström, I find it possible to view the human psyche as a physical phenomenon. During therapy 'Playfulness' (Kroebner, 1963) is a way to cope. This might spread some light on Schilder's view (6.1) that parents need an emotional inner balance to be able to guide their child. Describing Schilder's theories, Kestenberg (1984) uses the expression 'regression in service of parenting' meaning that "In each phase of parenthood, parents, especially mothers, regress with their children. This gives them a second chance to reorganize their psyche. In the process of reorganization, parental clashes with babies, toddlers, and older children can be ameliorated" (p.117). When the nervous system is ontogenetically set on each developmental level the process will be irreversible. This means that no more regressions are anticipated and the transformations gained will guide further development until the next unstable level is reached.

\section{Conclusion}

Learning disorders constitute huge problems in many children and youngsters today. Unfortunately, possible connections between learning disorders and sensorimotor 
immaturity have so far been disputed (Hattie, 2009). I argue that one reason why studies have failed to find a connection is that the power of the gravitational force and the vestibular system have been neglected. My conclusion is that sensorimotor development could be an emergent property of vestibular stimulation and the inhibition of behavioral movement patterns. Summing up the assumptions in 2.5, I propose that therapy according to RB creates a change from within, a second order change, and that this is one prerequisite for sustainable academic achievement. Unfortunately, much of the remedial education offered today seems to be based on the principle of 'more of the same', a first order change, i.e., if you can't read, read more. A challenge for the educational system will be to accept that some children have to regress in order to progress. During this period of transition, information and education have to be in balance. From my point of view it is highly possible that learning disabilities to a higher degree than previously realized are due to sensorimotor immaturity. It is equally highly possible that too many people through out history have been wrongly diagnosed as mentally retarded or have been misunderstood because of problems originating in sensorimotor immaturity. For science to be able to move the complicated issue of learning disorders closer to a coherent view it will have to cooperate over faculty borders. In a way, we are in a situation today similar to the one scientists were in a century ago, though on a higher level. Through the observation of behaviour, theories have been developed and through measurement, improvements perceived as possible. What is needed for the future is a more thorough synthesis of first/third person account, measurement and neuroscience. Boyle (2008) has proposed "a three-tiered intertheoretic model of explanation in which there is explanatory coherence across three levels of investigation: phenomenology, psychology and neuroscience" (p.37). Such a triangulation should make it possible to understand what happens in the brain during RB and during other kinds of therapy. Until then we have to rely on observations and measurements.

\section{Acknowledgement}

I am grateful to Bo Ahrenfelt, Matti Bergström, Irene Niklasson, Torsten Norlander, Peder Rasmussen, Marie Shaw and David Shaw for valuable feed back and support.

\section{References}

Ahrenfelt, B. (2001). Förändring som tillstaind [Change as a state of being] Lund, Sweden: Studentlitteratur.

Ahonen, T., Kooistra, L., Viholainen, H., \& Cantell, M. (2004). Developmental motor learning disability. A neuropsychological approach. In D. Dewey \& D. Tupper (Eds.) Developmental motor disorders. A neuropsychological perspective. New York, NY: The Guildford Press. Pp. 265-290.

American Psychiatric Association, APA. (1994). Diagnostic and statistical manual of mental disorders. (4:th ed). Washington, DC: American Psychiatric Association.

Anastasia, A., Urbina, S. (2007). Psychological testing. New Deli, India: Prentice-Hall.

Annell, A.L. (1949). School problems in children of average or superior intelligence: A preliminary report. Journal of Mental Science. 95, 901-909.

Arendt, H. (2006). Between past and future. New York, NY: Penguin Books.

Aristotle (1992). Introduction to Aristotele, edited, with introductions, by Richard McKeon. New York, NY: Random House Inc. 
Ayd Jr, F.J. (2000). Lexicon of psychiatry, neurology, and the neurosciences. Philadelphia, PA: Lippincott Williams \& Wilkins.

Ayres, A.J. (1973). Sensory integration and learning disorders. Los Angeles, CA: Western Psychological Services.

Ayres, A.J. (1979). Sinnenas samspel hos barn. [Sensory integration and the child]. Stockholm: Psykologiförlaget. [in Swedish].

Bergström, R.A.M. (1963). On the physiology of the meso-diencephalic extrapyramidal system, with special reference to the pathogenesis of involuntary movements. Acta Neurologica Scandinavica. 39(4), 52-60.

Bergström, R.M. (1964). Über das Wahrnehmen der Zeit als Wahrnehmen der Bewegung. [About the perception of time as perception of movement]. Annals Academiae Scientiarum Fennicae. Series A. 106, 2.

Bergström, R.M. (1967). Neural macrostates. An analysis of the function of the information carrying system of the brain. Synthese, 17, 425-443.

Bergström, R. M. (1972). Neural micro- and macrostates. In G. Newton \& A.H Riesen (Eds.) Advances in psychobiology. Vol.1. London: John Wiley \& Sons

Bergström, M. (1989). Meaning and the living brain. In P. Pylkkänen (Ed.) The search for meaning. The new spirit in science and philosophy. Wellingborough, Northamptonshire, UK: Crucible.

Bergström, M. (1997). Svarta och vita lekar [Black and white games]. Stockholm: Wahlström och Widstrand. [in Swedish]

Berkow, R. (Ed.) (1989). The Merck Manual of Diagnosis and Therapy. 15th ed. Third printing Rahway, NJ: Merck and Co., Inc.

Berthoz, A. (2000). The brain's sense of movement. Cambridge, MA: Harvard University Press.

Binet, A., Simon, Th. (1914). Mentally defective children. London: Edward Arnold.

Bloom, F.E., Lazerson, A. ( 1988). Brain, mind, and behavior. New York, NY: W.H. Freeman and Company.

Bollas, C. (1987). The shadow of the object. New York, NY: Columbia University Press.

Boyle, N. (2008). Neurobiology and phenomenology. Towards a three-tiered intertheoretic model of explanation. Journal of Consciousness Studies, 15 (3), 34-58.

Brodal, A. (1960). Fiber connections of the vestibular nuclei. In G.L. Rasmussen, \& W.F. Windle (Eds.), Neural mechanisms of the auditory and vestibular systems. Springfield, ILL: Charles C. Thomas Publisher.

Brodal, P. (2004). The central nervous system. Structure and function. Oxford: Oxford University Press.

Brookes, R., Tinkler, S., Nicholson, R., Fawcett, A. (2010). Striking the right balance: Motor difficulties in children and adults with dyslexia. Dyslexia:An Intenational Journal of Research and Practice, 16 (4), 358-373.

Cairney, J., Hay, J.A., Faught, B.E., \& Flouris, A. (2006). Developmental coordination disorder and aerobic fitness: is it all in their heads or is measurement still the problem? American Journal of Human Biology, 18, 66-70.

Cairney, J., Veldhuizen, S., \& Szatmari, P. (2010). Motor coordination and emotionalbehavioral problems in children. Current Opinion in Psychiatry, 23(4), 324-329.

Capute, A.J., \& Accardo, P.J. (1991). Developmental disabilities in infancy and childhood. Baltimore, MD: Paul Brooks. 
Carpenter, M.G., Adkin, A.L., Brawley, L.R., \& Frank, J.S. (2006). Postural, physiological and psychological reactions to challenging balance: does age make a difference? Age and Agening, 35, 298-303.

Carr, N. (2010). The shallows. How the internet is changing the way we think, read and remember. London: Atlantic Books.

Casaer, P. (1993). Development of motor functions: a 'developmental neurological' approach. In A. Kalverboer, B. Hopkins, \& R. Geuze (Eds.) Motor development in early and later childhood: longitudal approaches. Cambridge: Cambridge University Press.

Cawley, J., Spiess, C. (2008). Obesity and skills attainment in early childhood. Economics and Human Biology, 6, 388-397.

Cherng, R.J., Chen, J.J., \& Su, F.C. (2001). Vestibular system in performance of standing balance of children and young adults under altered sensory conditions. Perceptual and Motor Skills, 92, 1167-1179.

Chruickshank W.M.(1981). A new perspective in teacher education: The neuroeducator. Journal of Learning Disabilities, 14(6), 337-341,367.

Clarke, E., Jacyna, L.S. (1987). Nineteenth-century origins of neuroscientific concepts. Berkeley and Los Angeles, CA: University of California Press.

Crutchfield, C.A., \& Barnes, M.R. (1993). Motor control and motor learning in rehabilitation. Atlanta, GA: Stokesville Publishing.

Dalton, T.C., Bergenn, V.W. (2007). Early experience, the brain, and consciousness. An historical and interdisciplinary synthesis. New York, NY: Lawrence Erlbaum Associates.

De Vries, J.I.P., Visser, G.H.A., Prechtl, H.F.R. (1984). Fetal motility in the first half of pregnancy. In H.F.R Prechtl (Ed.) Continuity of neural functions from prenatal to postnatal life. Oxford, Great Britain: Spastics International Medical Publications.

De Raeymaecker, D.M. (2006). Psychomotor development and psychopathology in childhood. International Review of Neurobiology, 72, 83-101.

Doll, E.A., Phelps, W.M., \& Melcher, R.T. (1932). Mental deficiency due to birth injuries. New York, NY: Macmillan Co.

Ecclestone, K., Hayes, D. (2009). The dangerous rise of therapeutic education. Oxon, UK: Routledge.

Editorial. (1962). Clumsy Children. British Medical Journal. Saturday December 22, pp. 16651666.

Eliot, L. (2000). What's going on in there. How the brain and mind develop in the first Five years of life. New York, NY: Bantam.

Erikson, E. (1987). Childhood and society. London: Paladin.

Faught, B.E., Hay, J.A., Carney, J., \& Flouris, A. (2005). Increased risk for coronary vascular disease in children with developmental coordination disorder. The Journal for Adolescent Health, 37, 376-380.

Feldenkrais, M. (1988). Body and mature behaviour. A study of anxiety, sex, gravitation $\mathcal{E}$ learning. Tel-Aviv, Israel: ALEF Ltd.

Feng, L., Cheng, J., \& Wang, Y.F. (2007). [Motor coordination function of attention deficit hyperactivity disorder (review)]. Beijing Da Xue Bao, 18, 333-336.

Field, J., Blythe, P. (1989). Towards developmental re-education. Wichenford, UK: Field Educational Publishing.

Finger, S. (1994). Origins of neuroscience. Oxford: Oxford University Press. 
Flugel, J.C. (1933). A hundred years of psychology. London: Duckworth.

Franco, E.S., Panhoca, I. (2008). Vestibular function in children underperforming at school. Revista Brasileira de Otorhinolaryngologia. 74 (6), 815-825.

Furedi, F. (2009). Wasted. Why education isn't educating. London: Continuum International Publishing Group.

Gazzaniga, M.S. (1992). Nature's mind. The biological roots of thinking, emotions, sexuality, language and intelligence. London: Penguin.

Gesell, A. (1988). The embryology of behavior. The beginning of the human mind. London: Mac Keith Press.

Gillberg, C., Kadesjö, B. (2009). ADHD with developmental coordination disorder. In T. E. Brown (Ed.) ADHD Comorbidities. Handbook for ADHD complications in children and adults. Arlington, VA: American Psychiatric Publishing, Inc.

Gillberg, C. (2010). The ESSENCE in child psychiatry: Early symptomatic syndromes elicting neurodevelopmental clinical examinations. Research in Developmental Disabilities, 31(6), 1543-1551.

Goddard, S. (1990). A developmental basis for learning difficulties and language disorders. INPP Monograph Series. No.1. Chester, UK: INPP.

Goddard, S (2002). Reflexes, learning and behavior: A window into the child's mind. Eugene, OR: Fern Ridge Press.

Goddard Blythe, S (2009). Attention, balance, and coordination. The A.B.C. of learning success. Chichester, West Sussex, UK: John Wiley \& Sons Ltd.

Goldthwait, J.E., Brown, L.T., Loring, T.S., \& Kuhns, J.G. (1937). Body mechanic. In the study and treatment of disease. Philadelphia, NJ: J.B. Lippincott Company.

Geuze, R.H. (2005). Postural control in children with developmental coordination disorder. Neural Plasticity, 12, 183-196.

Gregory, R.D (Ed.) (2004). The Oxford Companion to the Mind. Oxford: Oxford University Press.

Guyton, A.C. (1991). Basic neuroscience: anatomy and physiology. Philadelphia, PA: Saunders.

Hasnulin, V.I., Hasnulina, A.V., \& Sevostyanova, E.V. (2004). Northern cardiometeopathies. Novosibirsk, Russia: Creative Union «South-West».

Hattie, J. (2009). Visible learning. A synthesis of over 800 meta-analyses relating to achievement. Oxon: Routledge.

Havard, C.W.H.(Ed.) (1990). Black's Medical Dictionary. 36th edition. London: A\& C Black (Publishers) Limited.

Heller-Roazen, D. (2009). The inner touch. Archaeology of a sensation. Brooklyn, NY: Zone Books.

Holle, B. (1990). Personal communication and an unpublished article.

Hubbard, D.G. (1971). The skyjacker. His flights of fantasy. New York, NY: The Macmillan Company.

Hubbard, D.G., Wright, C.G. (1984). The emotion of motion. Functions of the Vestibular apparatus. In D.A Shaskan, \& W.L. Roller (Eds.), Paul Schilder. Mind explorer (pp.161-182). New York, NY: Human Sciences Press.

Humprey, T. (1965). Embryologic differentiation of the vestibular nuclei in man correlated with functional development. In I. Kirikae (Ed.), Vestibular and oculomotor problems: Extraordinary meeting of the Japan society of vestibular research. Tokyo: University of Tokyo. 
Hydén, H. (1961). Biochemical aspects of brain activity. In S. Farger, \& R. Wilson (Eds.), Man and civilization: Control of the mind. New York, NY: McGraw-Hill.

Illingworth, R.S. (1987). The development of the infant and young child: Normal and abnormal. London: Churchill Livingstone.

Itard, J.M.G. (1932). The wild boy of Aveyron. New York, NY: Century Co.

Jacobs, L., Gossman, M.D. (1980). Three primitive reflexes in normal adults. Neurology, 30, 184-188.

Johansen, K. V. (1993). Lyd, horelse og sprogudvikling. [Sound, hearing and the development of language]. Horsens,Denmark: Forlaget Aalokke a/s. [in Danish]

Kadesjö, B., Gillberg, C. (1998). Attention deficits and clumsiness in Swedish 7-year -olds. Developmental Medicine and Child Neurology,40, 796-804.

Kahn, E., Cohen, L.H. (1934). Organic drivenness. A brain-stem syndrome and an experience. New England Journal of Medicine,210(14), 748-756.

Karlsson, G. (1995). Psychological qualitative research. Stockholm: Almquist \& Wiksell.

Kegan, R. (1994). In over our heads. The mental demands of modern life. Cambridge, MA: Harvard University Press.

Kestenberg, J.S. (1984). The role of movement patterns in diagnosis and prevention. In D.A Shaskan, \& W.L. Roller (Eds.), Paul Schilder. Mind explorer (pp.97-160). New York, NY: Human Sciences Press.

Klosovskii, B.N. (1963). The development of the brain and its disturbance by harmful factors. New York, NY: Pergamon Press LTD.

Konopka, A.K. (2007). Basic concepts of system biology. In A.K. Konopka (Ed), Systems biology. Principles, methods, and concepts. Boca Raton, FL: CRC Press.

Kris, E. (1952). Psychoanalytic explorations in art. New York, NY: International Universities Press.

Kroebner, T.C. (1963). The coping functions of the ego mechanism. In R.W. White (Ed.), The study of lives. Essays in personality in honour of Henry A. Murray (pp.178-198) New York: Atherton Press.

Larsen, E.J. (1931). A Neurologic-etiologic study on 1000 mental defectives. Acta psychiat. et neurol.,6, 37-54.

Larsen, W.J. (1993). Human embryology. London: Churchill Livingstone.

Levin, F.M. (2003). Psyche and brain. The biology of taking cures. Madison, CT: International Universities Press.

Lin, S.I., Woollacott, M.H., \& Jensen, J.L. (2004). Postural response in older adults with different levels of functional balance capacity. Aging, Clinical and Experimental Research, 16, 369-374.

Loewald, H.W. (1981). Regression: Some general considerations. Psychoanalytic Quaterly, 50, 22-43.

Lindqvist, E., Vestman, R., (2011). The labor market returns to cognitive and non-cognitive ability: Evidence from the Swedish enlistment. American Economic Journal:Applied Economics, 3(1), 101-128.

Lundborg, P., Nystedt, P.,\& Rooth, D.O. (2011). Unga feta mäns magra inkomster - vad vet vi om orsaken? [Young fat men with small salaries - for what reasons?] Ekonomisk debatt, 39(4), 44-54.

MacKenzie, D. (2000). What a downer. We may have to abandon our dreams of colonising space. New Scientist, 15 July, 22. 
Mainzer, K. (1994). Thinking in complexity. The complex dynamics of matter, mind and mankind. Heidelberg: Springer-Verlag.

Maurer, D., \& Maurer, C. (1989). The world of the newborn. London: Viking.

McGraw, M.B. (1995). General principles of growth. In T.C. Dalton \& V.W. Bergenn (Eds.), Beyond heredity and environment: Myrtle McGraw and the maturation controversy. Boulder, CO: Westview Press.

McPhillips, M., Hepper, P.G., \& Mulhem, G. ( 2000). Effects of replicating primaryreflexmovements on specific reading difficulties in children: A randomised, double blind, controlled trial. The Lancet, 355, 537-541.

Mehler, J., Dupoux, E. (1994). What infants know. The new cognitive science of early development. Oxford, UK: Blackwell.

Mitchell, A. (2003). Neuropsychiatry and behavioural neurology explained: Diseases, diagnosis, and management. Philadelphia, PA: Saunders.

Morrison, D.C. (1985). Neurobehavioural and perceptual dysfunction in learning disabled children. Lewiston, NY: Hogrefe.

Mycklebust, H.R. (1983). Toward a science of learning disabilities. Journal of Learning Disabilities, 16(1), 17-18.

Nadi, R., Luxon, L.M. (2008). Development and assessment of the vestibular system. International Journal of Audiology, 47(9), 566-577.

Nathanson, D.L. (1994). Shame and pride. Affect, sex, and the birth of the self. New York, NY: W.W. Norton \& Co, Inc.

Nicolis, G. (1993). Physics of far-from-equilibrium systems and self-organisation. In P. Davies (Ed.), The new physics. Cambridge: Cambridge University Press.

Niklasson, M., Niklasson, I. (1999a). Retraining for Balance-Physiological Test. Mönsterås, Sweden: Vestibularis.

Niklasson, M., Niklasson, I. (1999b). Retraining for Balance-Orientation and Balance Test. Mönsterås, Sweden: Vestibularis.

Niklasson, M., Niklasson, I. (2007a). Retraining for Balance-Physiological Test Revised. Mönsterås, Sweden: Vestibularis.

Niklasson, M., Niklasson, I. (2007b). Retraining for Balance- Orientation and Balance Test Revised. Mönsterås, Sweden: Vestibularis.

Niklasson, M., Niklasson,I., \& Bergström, M. (1999). Retraining for Balance-Methods. Mönsterås, Sweden: Vestibularis.

Niklasson, M., Niklasson,I., \& Bergström, M. (2007). Retraining for Balance-Methods Revised. Mönsterås, Sweden: Vestibularis.

Niklasson, M., Niklasson, I., \& Norlander, T. (2009). Sensorimotor therapy: Using stereotypic movements and vestibular stimulation to increase sensorimotor proficiency of children with attentional and motor difficulties.Perceptual and Motor Skills, 108, 643-669.

Niklasson, M., Niklasson, I., \& Norlander, T. (2010). Sensorimotor therapy: Physical and Psychological regressions contribute to an improved kinesthetic and vestibular capacity in children and adolescents with motor difficulties and concentration problems. Social Behavior and Personality.38(3),327-346.

Niklasson, M., Rasmussen, P., \& Norlander, T. (2010). Vestibulär/sensomotorisk terapi finns också i Sverige [Vestibular/sensorimotor therapy also in Sweden].Läkartidningen, 107(43), 2663. 
Odent, M. (1986). Primal health. A blueprint for our survival. London: Century Hutchinson Ltd.

Okamoto, H., Stracke, H., Ross, B., Kakigi, R., \& Pantev, C. (2007). Left hemispheric dominance during auditory processing in noisy environment. BioMed Central, 5, doi: 10.1186/1741-7007-5-52.

Orenstein, M. (2000). Smart but stuck. What every therapist needs to know about learning disabilities and imprisoned intelligence. Bingham, NY: The Hayworth Press.

Ornitz, E.M. (1983). Normal and pathological maturation of vestibular function in the human child. In R. Romand (Ed.), Development of auditory and vestibular systems. New York, NY: Academic Press, Inc.

Orton, S.T. (1937). Reading, writing and speech problems in children. New York, NY: W.W Norton \& Company, Inc.

Oschman J.L. (2000). Energy medicine. The scientific bases. Oxford: Churchill Livingstone.

Ozer, M.N. (1968). The neurological examination of school-age children. Journal of Learning Disabilities, 1(1), 87-89.

Papaseit, C., Pochon, N., \& Tabony, J. (2000). Microtubule self-organization is gravity dependent. Proceedings of the National Academy of Sciences of the United States of America. 97(15), 8364-8368.

Paulson, G., Gottlieb, G. (1968). Development reflexes: The reappearance of foetal and neonatal reflexes in aged patients. Brain, 91, 37-52.

Pennigton, B. F. (2009). Diagnosing learning disorder. A neurological framework. New York, NY: The Guilford Press.

Pirsig, R.M. (1991). Lila - an inquiry into morals. London: Bantam Press.

Pless, M. Developmental coordination disorder in pre-school children: effects of motor skill intervention, parent's descriptions, and short term follow-up of motor status. Unpublished doctoral dissertation, Uppsala University, Sweden.

Polanczyk, G., de Lima, M.S., Horta, B.L., Biederman, J., \& Rohde, L.A. (2007). The worldwide prevalence of ADHD: a systematic review and meta regression analysis. The American Journal of Psychiatry, 164, 942-948.

Polatajko, H.J. (1999). Developmental Coordination Disorder (DCD): alias, the clumsy child syndrome. In K. Whitmore, H. Hart, \& G. Willems (Eds.), A neurodevelopmental approach to specific learning disorders. London: Mac Keith Press. Pp. 119-133.

Polatajko, H.J., Rodger, S., Dhillon, A., \&Hirji, F. (2004). Approaches to management of children with motor problems. In D. Dewey \& D. Tupper (Eds.) Developmental motor disorders. A neuropsychological perspective. New York, NY: The Guildford Press. Pp. 461-486.

Prechtl, H.F.R. (1984). Continuity and change in early neural development. In H.F.R Prechtl (Ed.), Continuity of neural functions from prenatal to postnatal life. Oxford, Great Britain: Spastics International Medical Publications

Prechtl, H.F.R. (1993). Principles of early motor development in the human. In A. Kalverboer, B. Hopkins, \& R. Geuze (Eds.) Motor development in early and later childhood: longitudal approaches. Cambridge: Cambridge University Press.

Preyer, W. (1923). Die Seele des Kindes [The Soul of the Child]. Leipzig: Th. Griebens Verlag.

Preyer, W. (1885). Spezielle Physiologie des Embryo [Particular physiology of the embryo]. Leipzig: Th. Griebens Verlag.

Pribram, K. (1999). Brain and the composition of conscious experience. Journal of Consciousness Studies, 6, May: 19-42. 
Prigogine, I., Stengers, I. (1984). Order out of chaos. Man's new dialogue with nature. London: Heinemann

Prigogine, I. (2003). Is future given? River Edge, NJ: World Scientific Publishing.

Rasmussen, P., Gillberg, C. (2000). Natural outcome of ADHD with developmental coordination disorder at age 22 years: a controlled, longitudinal, community-based study. Journal of the American Academy of Child and Adolescent Psychiatry,39, 14241431.

Ravitch, D. (2000). Left back. A century of failed school reforms. New York, NY: Simon \& Schuster.

Rees, M. (2000). Just six numbers. New York, NY: Basic Books.

Reinold, E. (1976). Beobachtung fetaler Aktivität in der ersten Hälfte der Gravidität mit dem Ultraschall [Observation of fetal activity in the first half of pregnancy with ultrasound]. Pädiatrie und Pädologie, 6, 274-279.

Restak, R.M. (1979). The brain. The last frontier. New York, NY: Warner Books.

Robbins, J. (1977). Vestibular integration. Man's connection to the earth. Somatics, 1, 27-36.

Rodnitzky, R.L. (1988). Van Allen's pictorial manual of neurological tests. Chicago, ILL: Yearbook Medical Publications. Pp. 8-9.

Ronca, A.E., Alberts, J.R. (2000). Effects of prenatal spaceflight on vestibular responses in neonatal rats. Journal of Applied Physiology, 89(6), 2318-2324.

Schilder, P. (1933). The vestibular apparatus in neurosis and psychosis. Journal of Nervous and Mental Disease, 78, 1-23, 139-164.

Schilder, P. (1942). Mind: Perception and thought in their constructive aspects. Freeport, NY: Books for Libraries Press.

Schilder, P. (1964). Contributions to developmental neuropsychiatry. New York, NY: International Universities Press, Inc.

Schilder, P. (1971). Mind: Perception and thought in their constructive aspects. Freeport, New York: Books for Libraries Press.

Schrödinger, E. (1992). What is life? with Mind and Matter and Autobiographical Sketches. Cambridge: Cambridge University Press.

Scrimali, T. (2008). Entropy of mind and negative entropy. A cognitive and complex approach to schizophrenia and its therapy. London: Karnac Books.

Silver, A.A. (1951). Diagnosis and prognosis of behavior disorder associated with organic brain disease in children. Journal of Insurance Medicine, 6, 38-42.

Simon, R.P, Aminoff, M.J., \& Greenberg, D.A. (1989). Clinical neurology. Englewood Cliffs, NJ: Prentice-Hall. (p.110).

Sininger, Y.S., \& Cone-Wesson, B. (2004). Asymmetric cochlear processing mimics hemispheric specialization. Science, 305, 1581.

Stanley-Jones, D., Stanley-Jones, K. (1960). The kybernetics of natural systems. A study in patterns of control. London, Great Britain: Pergamon Press.

Stratton, G.M. (1917). Theophrastus and the Greek physiological psychology before Aristotele. London, Allen \& Unwin.

Strauss, A.A., Lehtinen, L.E. (1947). Psychopathology and education of the brain-injured child. New York, NY: Grune \& Stratton, Inc.

Tallal, P., Miller, S., \& Holly Fitch, R. (1993). Neurological basis of speech: a case for preeminence of temporal processing. In P. Tallal, A.M. Galaburda, R.R Llinas, \& C. von Euler (Eds.), Temporal information processing in the nervous system, special 
reference to dyslexia and dysphasia. New York: Annals of the New York Academy of Sciences. (No. 682). Pp. 27-47.

Tallis, F. (2002). Hidden minds. A history of the unconscious. London: Profile Books Ltd.

Tansley, A.E. (1967). Reading and remedial reading. London, Routledge and Kegan Paul.

Thelen, E. (1979). Rythmical stereotypes in normal human infants. Animal behaviour, 27, 699715.

Thelen, E. (2000). Motor development as foundation and future of developmental psychology. International Journal of Behavioral Development, 24(4), 385-397.

Teitelbaum, P. (1967). Physiological psychology. Englewood Cliffs, N.J: Prentice-Hall, Inc.

Todd, M.E. (1937). The thinking body. Hightstown,NJ: Dance Horizons/Princeton book Co.

Torretti, R. (1999). The philosophy of physics. Cambridge: Cambridge University Press.

Touwen, B.C.L. (1984). Primitive reflexes-conceptional or semantic problem. In H.F.R Prechtl (Ed.), Continuity of neural functions from prenatal to postnatal life. Oxford, Great Britain: Spastics International Medical Publications.

Van Boxtel, M.P., Bosma, H., Jolles, J., \& Vreeling, F.W. (2006). Prevalence of primitive reflexes and the relationship with cognitive change in healthy adults: a report from the Maastricht aging study. Journal of Neurology, 253(7), 935-941.

Von Bertalanffy, L. (1993). General systems theory. Foundations, development, applications. Revised version. New York, NY: George Braziller, Inc.

Vose, R.H. (1986). Agoraphobia. London: Faber \& Faber.

Watzlawick, P., Weakland, J.H., \& Fish, R. (1974). Change. Principles of problem formation and problem resolution. New York, NY: W.W. Norton \& Company, Inc.

Wade, N.J. (2009). The search for a sixth sense. The cases for vestibular, muscle, and temperature senses. In D. Howes (Ed.) The sixth sense reader. Oxford, UK: Berg.

Werner, H. (1957). The concept of development: An issue in the study of human behavior. Minneapolis, MI: University of Minnesota Press.

Windle, W.F. (1971). Physiology of the fetus. Relation to brain damage in the perinatal period. Springfield, IL: Charles C Thomas Publisher.

Woollacott, M.H. (1993). Early postnatal development of posture control: normal and abnormal aspects. In A. Kalverboer, B. Hopkins, \& R. Geuze (Eds.) Motor development in early and later childhood: longitudal approaches. Cambridge: Cambridge University Press.

Yochman, A., Ornoy, A., \& Parusch, S. (2006). Co-occurance of developmental delays among preschool children with attention-deficit hyperactivity disorder. Developmental Medicine and Child Neurology,48, 483-488. 


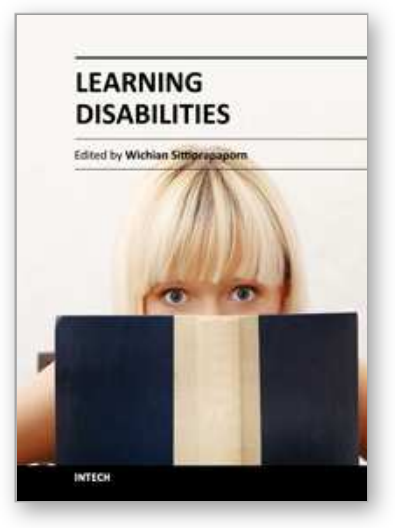

\author{
Learning Disabilities \\ Edited by Dr. Wichian Sittiprapaporn
}

ISBN 978-953-51-0269-4

Hard cover, 364 pages

Publisher InTech

Published online 14, March, 2012

Published in print edition March, 2012

Learning disability is a classification that includes several disorders in which a person has difficulty learning in a typical manner. Depending on the type and severity of the disability, interventions may be used to help the individual learn strategies that will foster future success. Some interventions can be quite simplistic, while others are intricate and complex. This book deserves a wide audience; it will be beneficial not only for teachers and parents struggling with attachment or behavior issues, but it will also benefit health care professionals and therapists working directly with special needs such as sensory integration dysfunction.

\title{
How to reference
}

In order to correctly reference this scholarly work, feel free to copy and paste the following:

Mats Niklasson (2012). Could Motor Development Be an Emergent Property of Vestibular Stimulation and Primary Reflex Inhibition? A Tentative Approach to Sensorimotor Therapy, Learning Disabilities, Dr. Wichian Sittiprapaporn (Ed.), ISBN: 978-953-51-0269-4, InTech, Available from:

http://www.intechopen.com/books/learning-disabilities/could-motor-development-be-an-emergent-propertypartly-of-vestibular-stimulation-and-primary-reflex-

\section{INTECH}

open science | open minds

\section{InTech Europe}

University Campus STeP Ri Slavka Krautzeka 83/A 51000 Rijeka, Croatia Phone: +385 (51) 770447

Fax: +385 (51) 686166 www.intechopen.com

\section{InTech China}

Unit 405, Office Block, Hotel Equatorial Shanghai No.65, Yan An Road (West), Shanghai, 200040, China 中国上海市延安西路65号上海国际贵都大饭店办公楼405单元 Phone: +86-21-62489820

Fax: +86-21-62489821 
(C) 2012 The Author(s). Licensee IntechOpen. This is an open access article distributed under the terms of the Creative Commons Attribution 3.0 License, which permits unrestricted use, distribution, and reproduction in any medium, provided the original work is properly cited. 